\title{
Effects of Mulching and Mulching with Mineral Fertilizers on the Floristic Composition of Oligotrophic Grasslands After Six Years
}

\author{
Ioan ROTAR, Florin PĂCURAR*, Roxana VIDICAN, Ágnes BALÁZSI, Anca BOGDAN, Vlad STOIAN \\ Faculty of Agriculture. University of Agricultural Sciences and Veterinary Medicine Cluj-Napoca, \\ Romania. \\ *Corresponding author:fpacurar@gmail.com
}

Bulletin USAMV series Agriculture 72(2)/2015

Print ISSN 1843-5246; Electronic ISSN 1843-5386

DOI 10.15835/buasvmcn-agr: 11736

\begin{abstract}
Mulching of grasslands was suggested by many that could be a feasible solution for the low productive systems to maintain their natural productivity and floristical diversity, when succesion of woody species is a threatening factor. In this middle-term experiment, we aimed to study the effects of new alternatives in Apuseni Mountains, like mulching and mulching with mineral fertilization, on the floristic structure of the oligotrophic grasslands. The experiment has started in 2009 and we followed the effects of the treatments in the $6^{\text {th }}$ year. The experiment design contains seven variants in five repetitions (randomized blocks) of mowing, mulching and mulching with different doses of fertilizers applied in different time. After six years, the treatments determined no changes in the main grassland type, but significant changes have taken place in the floristic compositions of the variants. The overall effects of the treatments are negative upon the phytodiversity in some of the variants. From this reason these has to be carefully recommended if there are conservational purposes.
\end{abstract}

Keywords: grassland management, mulching, fertilizing, floristic composition, low-input.

\section{INTRODUCTION}

Mulching of grasslands means mowing of the grass, cutting in small pieces with special equipment and leaving the green material in the soil for decomposing. Gaisler (2006) and Maskova (2009) suggested that mulching could be a feasible solution for the low productive systems to maintain the natural productivity and floristical diversity, when succession of woody species is a threatening factor (Doležal et al., 2011; Carboni et al., 2014). Tonn et al. (2010) highlighted that mulching could be an alternative solution for the conservation of semi-natural grasslands with high level of biodiversity.

In Romania, the first researches have focused on the effects of mulching upon the oligotrophic grasslands by Păcurar et al. (2011), in the Apuseni
Mountains, in order to establish new posibilities (alternatives) to maintain both the diversity and the natural productivity of oligotrophic grasslands. The results of Bogdan (2012) demonstrated that mulching and its combination with mineral or organic fertilizers causes no changes on the phytodiversity in short term (1-3 years). As it was highligted by Rotar et al. (2014), the same treatments cause minimal impact on the floristic composition after 4 years, but the changes could not be observed at the level of grassland type.

Following the hypothesis that traditionally managed oligotrophic grasslands sites are in functional equilibrium, we ask which management treatment will yield communities whose floristic composition are most similar to the traditional management regime. The aim of the study was to 
identify the suitability of different management techniques to retain these oligotrophic grasslands and to maintain their high biodiversity.

\section{MATERIALS AND METHODS}

The experiment started in 2009 in Poienile Ursului (1349 m), Ocoale Village, Gârda de Sus Commune, Apuseni Mountains, using a randomized block design with 7 treatments in 5 replications (table 1). The floristic composition was interpreted by Braun-Blanquet method, when the Poaceae species were in flower (in July, 2012). For the processing of floristic data, we used the PC-ORD. For data processing and interpretation we used the MRPP (Multi Response Permutation Procedure), multidimensional scaling NMDS, Summary (for the Shannon index and the number of species) and average abundance and dominance (Peck, 2010; McCune and Mefford, 2011). For the analysis of variance and to evaluate the effect of treatments applied on vegetation, we used the soft STATISTICA. The analysis of variance was performed by Breakdown and One-Way ANOVA type. To analyse in detail the effect of treatment on species with significant reaction, we used a comparative analysis, Post-hoc, the Fisher LSD type.

This paper summarizes the results of the sixth experimental year, showing the effect of treatments on plant species composition of grassland. NMS was carried out several times in autopilot mode, in order to minimize the stress. Distance measures was done with Sorensen (Bray - Curtis). The recommended solution for data presentation was tridimensional (stress 13.330). The coefficient of determination $\left(r^{2}\right)$ for the correlations between ordination distances and distances in the original $n$-dimensional space was 0.816 (Axis1 - 0.357; Axis2 - 0.281; Axis3 - 0.179). Vectors like mowing and mulching are correlated with Axis 3 (C mowing: $r=-0.548 ; \mathrm{M}-$ mulching $r=0.548$ ). Fertilizing with N25:P25:K25 (N) is correlated with Axis $1(\mathrm{r}=-0.552)$ and the P25:K25 (P-K) is not correlated with any of the axis.

\section{RESULTS AND DISCUSSION}

At grassland type level no changes were registered sfter 6 years of experiment, which is confirmed also by the concentration of plots in the ordination space (Fig. 1a and b). Nonetheless the results of MRPP (tabel 2) show significant differences between the floristic composition of the treatments (variants) in any of the cases.

A series of chages were caused by our treatments in the $6^{\text {th }}$ experimental year in the floristic composition (table 2). Agrostis capillaris L. responded positiveley to $1 \mathrm{M}$ and $1 \mathrm{Mu}+1 \mathrm{Mf}_{\mathrm{NPK}}$ $1 \mathrm{Mu}+1 / 2 \mathrm{Mf}_{\mathrm{NPK}}$ in comparison with control, fact that is in line with the findings of (Pavlu et al., 2012; Păcurar et al., 2012). The cover of Festuca rubra $\mathrm{L}$. was higher by the $2 \mathrm{Mu}$ and $1 \mathrm{Mu}+1 \mathrm{Mf}_{\mathrm{NPK}}$. The cover of the Poaceae was higher, significantly $(\mathrm{p}<0.05)$ at $2 \mathrm{Mu}$ and distinct significantly $(\mathrm{p}<0.001)$ in $1 \mathrm{Mu}+1 \mathrm{Mf}_{\mathrm{NPK}}$. The group of Cyperaceae and Juncaceae was influenced negatively by all of the treatments. The Fabaceae reduced significantly $(\mathrm{p}<0.05)$ their cover by the $2 \mathrm{Mu}$ and very significantly $(\mathrm{p}<0.01)$ at $1 \mathrm{Mu}+1 \mathrm{Mf}_{\mathrm{NPK}}$ and $1 \mathrm{Mu}+1 / 2 \mathrm{Mf}_{\mathrm{NPK}}$. In the first three experimental years these treatment had no influence on this species group (Bogdan, 2012).

Tab.1 Investigated treatments

\begin{tabular}{|c|c|c|}
\hline Treatments & Abbreviations & Applied treatments \\
\hline $\mathrm{T} 1$ & 1Mo - Control & Mowing once per a year, end of July - period for traditional hay making \\
\hline $\mathrm{T} 2$ & $1 \mathrm{Mu}$ & Mulching once per a year July \\
\hline T3 & $2 \mathrm{Mu}$ & Mulching twice per a year in July and September \\
\hline $\mathrm{T} 4$ & $1 \mathrm{Mu}+1 \mathrm{Mf}_{\mathrm{NPK}}$ & $\begin{array}{l}\text { Mulching once per a year (July) and mineral fertilizing with } \mathrm{N}_{25} \mathrm{P}_{25} \mathrm{~K}_{25} \\
\text { applied annually (April) }\end{array}$ \\
\hline $\mathrm{T} 5$ & $1 \mathrm{Mu}+1 / 2 \mathrm{Mf}_{\mathrm{NPK}}$ & $\begin{array}{c}\text { Mulching once per a year (July) and mineral fertilizing with } \mathrm{N}_{25} \mathrm{P}_{25} \mathrm{~K}_{25} \\
\text { applied once in two years (April) }\end{array}$ \\
\hline $\mathrm{T} 6$ & $1 \mathrm{Mu}+1 \mathrm{Mf}_{\mathrm{PK}}$ & $\begin{array}{c}\text { Mulching once per a year (July) and mineral fertilizing with } \mathrm{P}_{25} \mathrm{~K}_{25} \text { applied } \\
\text { annually (April) }\end{array}$ \\
\hline $\mathrm{T} 7$ & $1 \mathrm{Mu}+1 / 2 \mathrm{Mf}_{\mathrm{PK}}$ & $\begin{array}{c}\text { Mulching once per a year (July) and mineral fertilizing with } \mathrm{P}_{25} \mathrm{~K}_{25} \text { applied } \\
\text { once in two years (April) }\end{array}$ \\
\hline
\end{tabular}




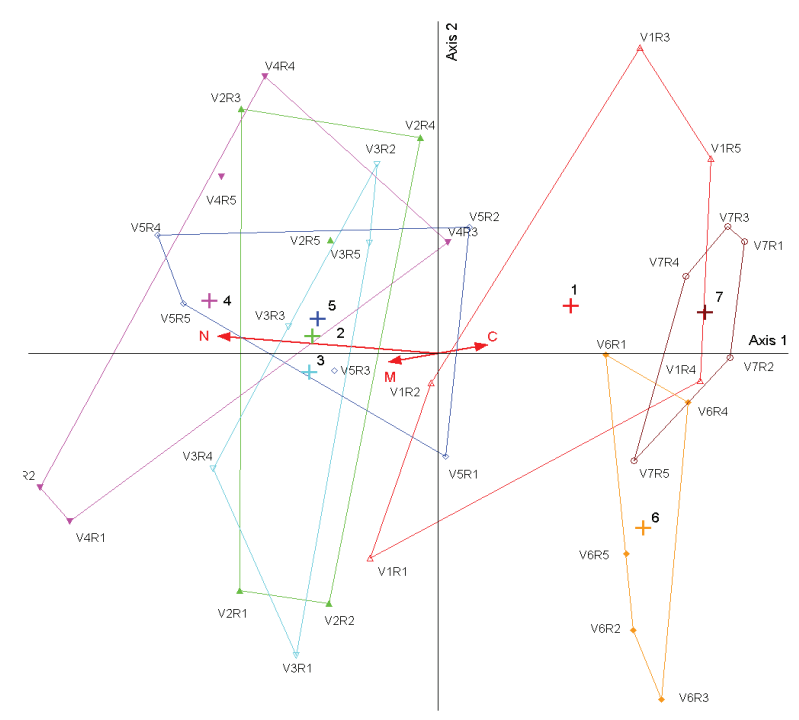

a) Axis 1 and axis 2

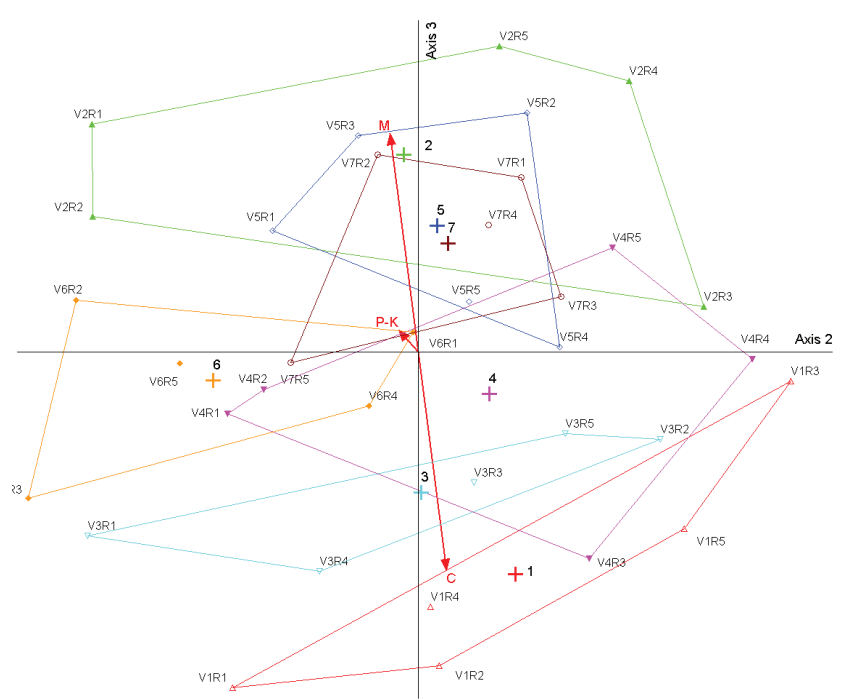

b) Axis 2 and axis 3

Fig. $1 \mathrm{a}$ and b Ordination of treatments influenced by mineral fertilizers (2014)

The plants form other botanical families maintained their cover, but species with cover under $1 \%$ increased significantly $(\mathrm{p}<0.05)$ by the $2 \mathrm{M}$ and $1 \mathrm{Mu}+1 / 2 \mathrm{Mf}_{\mathrm{PK}}$ and very significantly $(\mathrm{p}<0.001)$ by $1 \mathrm{Mu}+1 / 2 \mathrm{Mf}_{\mathrm{NPK}}$ in comparison with the control $(1 \mathrm{Mo})$. The number of species was decreased by $1 \mathrm{Mu}(\mathrm{p}<0.01), 1 \mathrm{Mu}+1 \mathrm{Mf}_{\mathrm{NPK}}(\mathrm{p}<0.05)$, $1 \mathrm{Mu}+1 / 2 \mathrm{Mf}_{\text {NPK }}(\mathrm{p}<0.05), 1 \mathrm{Mu}+1 / 2 \mathrm{Mf}_{\mathrm{PK}}(\mathrm{p}<0.05)$. The Shannon index was influenced negatively $(\mathrm{p}<0.05)$ by the $1 \mathrm{Mu}+1 \mathrm{Mf}_{\mathrm{NPK}}$.

As it is presented in Fig. 2a and b, mowing (C) had a positive influence on the species like Colchicum autumnale L. (medium tolerance - 5, by Păcurar and Rotar, 2014), Rhinanthus minor L. (medium tolerance - 5), and negative upon the species Ranunculus bulbosus L., that even if prefers frequent mowing (medium tolerance - 6), in our case prefered much more the conditions offered by mowing. Mulching (M) favoured Phleum montanum K. Koch. and disfavored the species favoured by mowing. Fertilizing with N25:P25:K25 in combination with mulching had a positive influence on Agrostis capillaris L., Festuca rubra L., Phleum montanum K. Koch. etc. and a negative one on Trifolium repens L., Arnica montana L., Polygala vulgaris $\mathrm{L}$., fact that is in line with others observations, mentioned before.

Considering that on both, international and national level only few reserches have focusing on the effects of mulching combined with mineral
Tab. 2 Comparison of the floristic composition of experimental variants (MRPP, 2014)

\begin{tabular}{ccccc}
\hline Treatments & $\mathrm{T}$ & $\mathrm{A}$ & $\mathrm{p}$ & Signif. \\
\hline V1 vs. V2 & $-3,677$ & 0,162 & 0,003 & $* *$ \\
\hline V1 vs. V3 & $-2,226$ & 0,090 & 0,030 & $*$ \\
\hline V1 vs. V4 & $-3,342$ & 0,159 & 0,006 & $* *$ \\
\hline V1 vs. V5 & $-3,610$ & 0,148 & 0,003 & $* *$ \\
\hline V1 vs. V6 & $-3,440$ & 0,124 & 0,003 & $* *$ \\
\hline V1 vs. V7 & $-4,058$ & 0,167 & 0,001 & $* *$ \\
\hline V2 vs. V3 & $-3,199$ & 0,142 & 0,008 & $* *$ \\
\hline V2 vs. V4 & $-1,650$ & 0,080 & 0,068 & ns \\
\hline V2 vs. V5 & $-1,197$ & 0,040 & 0,119 & ns \\
\hline V2 vs. V6 & $-4,793$ & 0,212 & 0,001 & $* *$ \\
\hline V2 vs. V7 & $-4,660$ & 0,228 & 0,001 & $* *$ \\
\hline V3 vs. V4 & $-1,423$ & 0,060 & 0,090 & ns \\
\hline V3 vs. V5 & $-2,076$ & 0,066 & 0,025 & $*$ \\
\hline V3 vs. V6 & $-4,196$ & 0,184 & 0,002 & $* *$ \\
\hline V3 vs. V7 & $-5,086$ & 0,251 & 0,001 & $* *$ \\
\hline V4 vs. V5 & $-2,323$ & 0,091 & 0,016 & $*$ \\
\hline V4 vs. V6 & $-4,915$ & 0,276 & 0,001 & $* *$ \\
\hline V4 vs. V7 & $-4,784$ & 0,302 & 0,001 & $* *$ \\
\hline V5 vs. V6 & $-4,286$ & 0,196 & 0,001 & $* *$ \\
\hline V5 vs. V7 & $-4,797$ & 0,234 & 0,001 & $* *$ \\
\hline V6 vs. V7 & $-3,521$ & 0,151 & 0,006 & $* *$ \\
\hline Note: T - T value A - A value, - p value, Signif.-Significance, ns -
\end{tabular}

Note: $T$ - T value, $A-A$ value, $p$ - $p$ value, Signif. - Significance, ns not significant 
Tab. 2 Floristic structure of grassland type (ANOVA and LSD tests)

\begin{tabular}{|c|c|c|c|c|c|c|c|c|}
\hline \multirow{2}{*}{\multicolumn{2}{|c|}{ Indicators for phytocoenosis }} & \multicolumn{7}{|c|}{ Treatments } \\
\hline & & $\mathrm{T} 1$ & $\mathrm{~T} 2$ & $\mathrm{~T} 3$ & $\mathrm{~T} 4$ & $\mathrm{~T} 5$ & $\mathrm{~T} 6$ & $\mathrm{~T} 7$ \\
\hline \multirow{2}{*}{$\begin{array}{l}\text { Grassland type } \\
\text { F.r.-A.c. }\end{array}$} & Agrostis capillaris L. & 11.25 & $17.50 * * *$ & 11.25 & $16.25^{* * *}$ & $13.75^{*}$ & 11.25 & 11.25 \\
\hline & Festuca rubra L. & 21.50 & 19.50 & $27.50^{* *}$ & $27.50^{* *}$ & 19.50 & 17.50 & 17.50 \\
\hline \multirow{4}{*}{ Econimic groups } & Poaceae & 36.50 & 39.50 & $41.95^{*}$ & $48.35^{* * *}$ & 37.00 & 32.40 & 33.75 \\
\hline & $\begin{array}{l}\text { Cyperaceae and } \\
\text { Juncaceae }\end{array}$ & 1.70 & $0.50^{\circ 00}$ & $0.50^{\circ 00}$ & $0.30^{\circ 00}$ & $0.50^{\circ 00}$ & $0.30^{\circ 00}$ & $0.10^{\circ \circ 0}$ \\
\hline & Fabaceae & 16.15 & 12.10 & $9.85^{\circ}$ & $8.25^{\circ \circ}$ & $9.00^{\circ 0}$ & 19.05 & 18.60 \\
\hline & OBF & 40.20 & 40.00 & 42.95 & 39.40 & 41.85 & 45.75 & 42.25 \\
\hline \multirow{3}{*}{$\begin{array}{l}\text { Species with } \\
\text { cover under } 5 \%\end{array}$} & $<5 \%$ & 14.00 & 12.00 & 20.00 & 13.00 & 19.00 & 18.00 & 11.00 \\
\hline & $<1 \%$ & 17.05 & 20.35 & $26.95^{*}$ & 17.60 & $28.60^{* *}$ & 24.75 & $25.85 *$ \\
\hline & $<0.1 \%$ & 9.50 & $7.00^{\circ \circ}$ & $6.30^{\circ}$ & $7.70^{\circ}$ & $5.50^{\circ 00}$ & $6.00^{\circ 00}$ & $6.10^{\circ 00}$ \\
\hline \multirow{2}{*}{ Phytodiversity } & $S$ & 32.00 & $27.20^{\circ 0}$ & 28.80 & $28.00^{\circ}$ & $27.60^{\circ}$ & 28.60 & $28.40^{\circ}$ \\
\hline & Shannon & 2.66 & 2.54 & 2.66 & $2.47^{\circ}$ & 2.75 & 2.79 & 2.77 \\
\hline
\end{tabular}

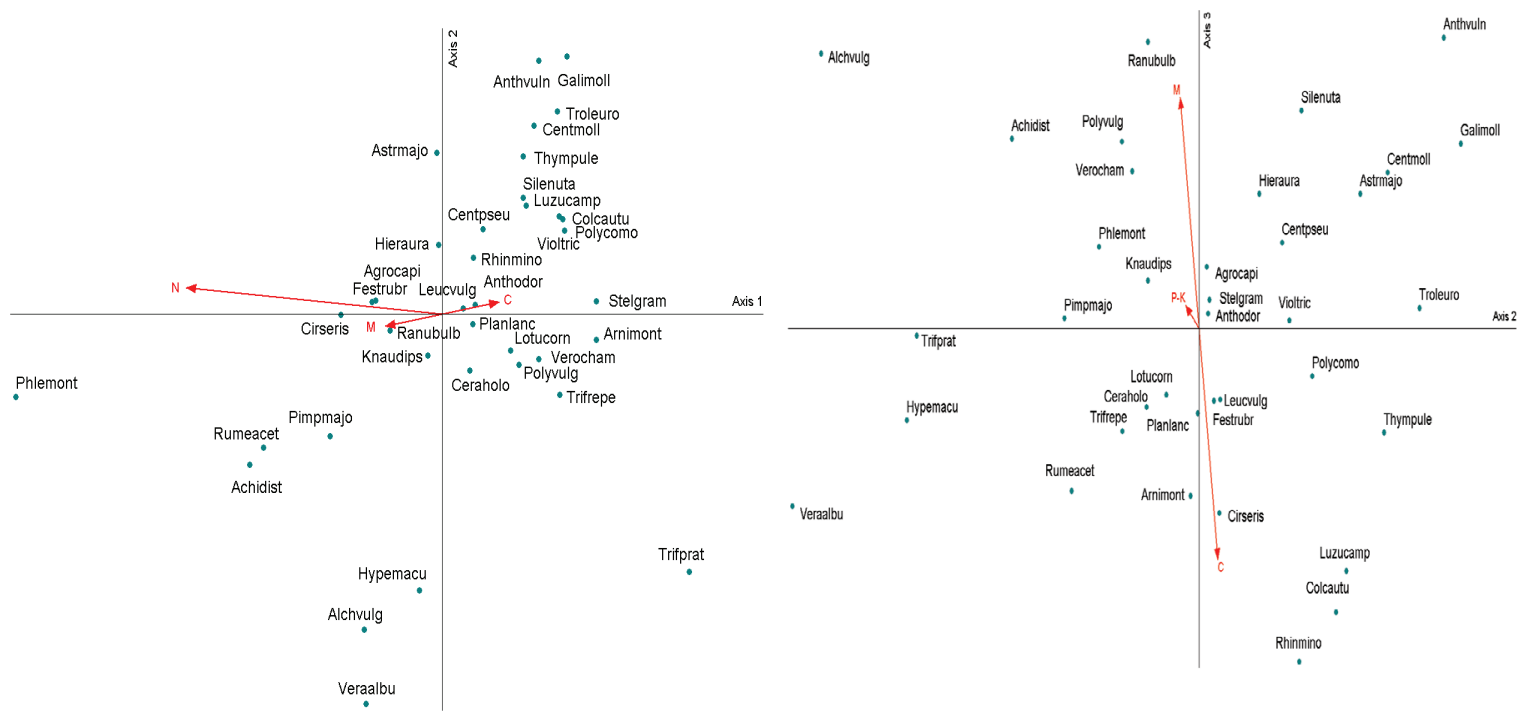

a) Axis 1 and axis 2

b) Axis 2 and axis 3

Fig. 2 a and b Ordination of species influenced by mineral fertilizers (2014)

fertilizing, is quite difficult to compare our results with the findings of others.

\section{CONCLUSION}

Our treatments could be considered as an alternative solution to maintain the oligotrophic grasslands floristic composition, but their recommendation on a large scale has to be analised prealably in function of the biodiversity conservation goals and to consider the longterm effects of those treatment upon the floristic composition.

\section{REFERENCES}

1. Bogdan A (2012). Cercetări privind folosirea şi menținerea pajiștilor montane cu low-input. Teză de doctorat. USAMV Cluj-Napoca. 
2. Carboni M, De Bello F, Janeček Š, Doležal J, Horník J, Lepš J, Klimešová J (2014). Changes in trait divergence and convergence along a productivity gradient in wet meadows. Agriculture, Ecosystems and Environment, 182, 96-105.

3. Doležal J, Mašková Z, Lepš J, Steinbachová D, De Bello F, Klimešová J, Květ J (2011). Positive long-term effect of mulching on species and functional trait diversity in a nutrient-poor mountain meadow in Central Europe. Agriculture, Ecosystems and Environment, 145(1), 10-28.

4. McCune B, Mefford MJ (2011). PC-ORD. Multivariate Analysis of Ecological Data. Version 6. MjM Software, Gleneden Beach, Oregon, U.S.A.

5. Pãcurar F, Rotar I, Bogdan A, Vidican R, Dale L (2012). The influence of mineral and organic long-term fertilization upon the floristic composition of Festuca rubra L.-Agrostis capillaris L. grassland in Apuseni mountains, Romania. Journal of Food, Agriculture and Environment, 10(1), 866879.

6. Păcurar F, Rotar I (2014) Metode de studiu și interpretare a vegetației pajiștilor. Risoprint Cluj-Napoca.

7. Păcurar F, Rotar I, Bogdan A, Vidican R (2011). Research concerning the structure and functioning of low-input grassland systems. Bulletin of University of Agricultural Sciences and Veterinary Medicine Cluj-Napoca. Agriculture, 68, 245-250.

8. Pavlů V, Gaisler J, Pavlů L, Hejcman M, Ludvíková V (2012). Effect of fertiliser application and abandonment on plant species composition of Festuca rubra grassland. Acta Oecologica, 45, 42-49.

9. Peck JE (2010). Multivariate Analysis for Community Ecologists: Step-by-Step using PC-ORD. MjM Software Design, Gleneden Beach, OR.

10. Rotar I, Păcurar F, Balázsi Á, Vidican R, Mălinaş A (2014). Effects of low-input treatments on Agrostis capillaris L.-Festuca rubra L. grasslands. The Future of European Grasslands, 298.

11. Tonn B, Briemle G, Schnyder H, Isselstein J, Taube F, Auerswald K, Hopkins A (2010). Minimum management intensity for maintaining and improving biodiversity of a mesotrophic semi-natural grassland. In Grassland in a changing world. Proceedings of the 23rd General Meeting of the European Grassland Federation, Kiel, Germany, 29th August-2nd September 2010. (pp. 747-749). Mecke Druck und Verlag. 